c. 3

\title{
Corps
}

ui Euyucers

Waterways Experiment

Station

Improvement of Operations and Management Techniques Research Program

The Application of a Decision Support System to U.S. Army Corps of Engineers

Civil Works O\&M Budget Analysis

by Stephen H. Scott

Approved For Public Release; Distribution Is Unlimited

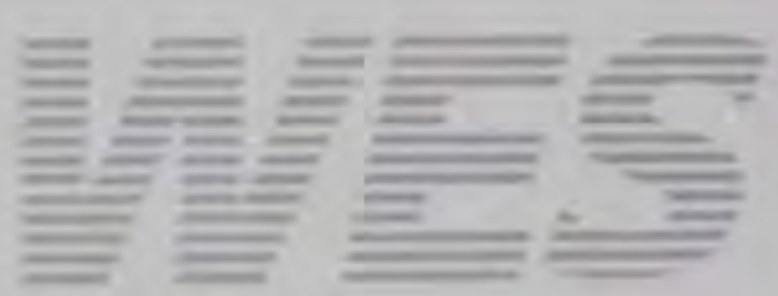

Prepared for Headquarters, U.S. Army Corps of Engineers 
Improvement of Operations

\section{The Application of a Decision Support System to U.S. Army Corps of Engineers Civil Works O\&M Budget Analysis}

by Stephen H. Scott

U.S. Army Corps of Engineers

Waterways Experiment Station

3909 Halls Ferry Road

Vicksburg, MS 39180-6199

Final report

Approved for public release; distribution is unlimited

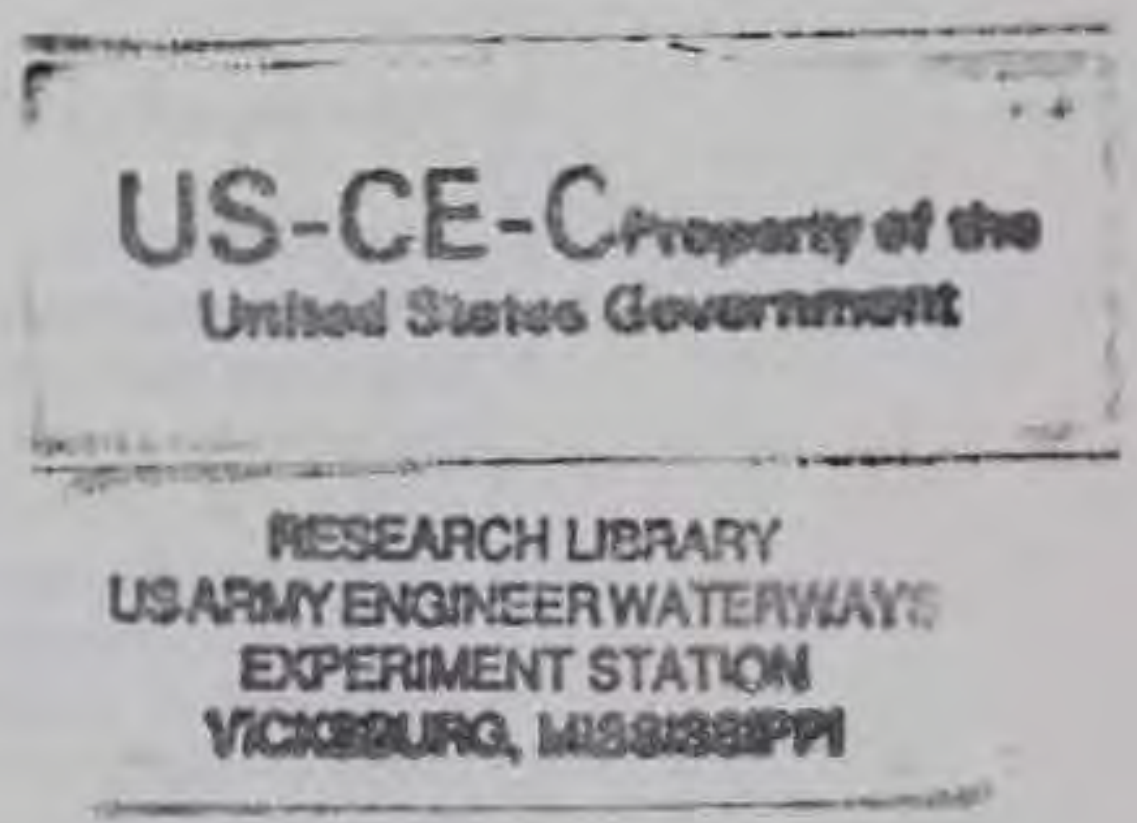


Work Function Analysis by Rank $\ldots \ldots \ldots \ldots \ldots \ldots \ldots \ldots$ A1 SF 298 


\section{Preface}

This study was conducted by the Hydraulics Laboratory (HL) of the U.S. Army Engineer Waterways Experiment Station (WES) during the period October 1990 to October 1994. The study was sponsored by the Headquarters, U.S. Army Corps of Engineers (HQUSACE), as a part of the Improvement of Operations and Management Techniques (IOMT) research program, Work Unit 32717, "The Application of Decision Support Systems to O\&M Budget Management," managed by HL. HQUSACE Technical Monitors for the IOMT research program were Mr. James Crews, Chief Technical Monitor, and Mr. Robert Daniel.

This report was prepared by Mr. Stephen H. Scoth, Estuarine Engineering Branch (EEB), Estuaries Division (ED), HL. Principal investigators for the work unit were Mr. Scott and Mr. Michael R. Walsh of the Institute of Water Resources (IWR). Technical assistance was provided by Ms, Connie L. Raaymakers and Mr. Edward J. Japel of the Construction Engineering Research Laboratory (CERL). Contractor support was provided by Mr. Craig A. Strus and Mr. Russ E. Robinson of Planning and Management Consultants, Limited, and Mr. Richard M. Males of RMM Technical Services. The development and testing of the prototype decision support software was done with the cooperation of Mr. Dave Harmon of HQUSACE and Mr. Rod Plybon of the Ohio River Division, U.S. Army Corps of Engineers.

The study was conducted under the gencral supervision of Mr. Frank A. Herrmann, Jr., Director, HL; and Mr. Richard A. Sager, Assistant Director, $\mathrm{HL}$; and under the direct supervision of Mr. William H. McAnally, Jr., Chief, ED, and W.D. Martin, Chief, EEB. Mr. Robert F. Athow, ED, was the IOMT Program Manager.

The research team gratefully acknowledges the contributions of Messrs. Harmon and Plybon, and Ms. Mary Supple and Mr. Jack Sirak of ORD during the development and testing of the Decision Support System (DSS) prototype.

At the time of publication of this report, Director of WES was Dr. Robert W. Whalin. Commander was COL Bruce K. Howard, EN. 
For further information on this report or on the Improvement of Operations and Management Research Program, please contact Mr. Robert F. Athow, Program Manager, at (601) 634-2135.

The contents of this report are not to be used for advertising, publication, or promotional purposes. Citation of trade names does not constitute an official endorsement or approval of the use of such commercial products. 


\section{Introduction}

\section{Background}

The goal of this Improvement of Operations and Management Techniques (IOMT) work unit was to provide decision support tools for increasing the efficiency and productivity of Civil Works O\&M project managers. The Corps of Engineers Civil Works O\&M budget totals approximately $\$ 1.4$ billion dollars yearly. This budget supports 700 major Corps of Engineers constructed projects such as locks, dams, and power plants, as well as many other projects that require O\&M funding for continued operation. The Civil Works budgeting process is a cooperative effort between the Corps of Engineers Districts, Divisions, and Headquarters, U.S. Army Corps of Engineers (HQUSACE). Budget packages are developed for individual projects at the field level (District and Division) on a personal computer based system (Automated Budget System (ABS)) and uploaded to HQUSACE for final budget development on a mainframe computer. The O\&M budget contains approximately 20,000 work functions ${ }^{1}$ for funding consideration. These budget submissions must fall within a funding ceiling provided by the Office of Management and Budget (OMB) for the O\&M General appropriations account. Work functions are prioritized for funding based on funding guidance set in a funding matrix provided by HQUSACE. During this ranking process, critical funding decisions must be made on funds allocation. Project benefits must be evaluated in terms of providing service to the public as well as providing a suitable economic return on O\&M dollars invested.

Analytical tools for ranking work functions and determining funding impact scenarios at HQUSACE were limited. The budget packages were submitted to HQUSACE for final budget preparation on a mainframe computer database. Based on the budget submissions from the field, HQUSACE creates a work function ranking independent of the District and Division ranks. This ranking results from numerous funding scenarios investigated by HQUSACE. Report

\footnotetext{
I The smallest element of work represented in the O\&M budget is a work function. It corresponds to a feature cost code or category code. For example, a work function may be the maintenance of a dam. This work function would consist of numerous tasks such as grass cutting, dam maintenance, or outlet works maintenance. It would fall under the feature cost code 621.11 for cost accounting purposes.
} 
generation and analysis to support the HQUSACE work function ranking were performed using the Structured Query Language (SQL) resident on the mainframe database. This method of analyzing and restructuring the budget was time consuming, limited in capability, and costly.

The Decision Support System (DSS) concept is based on the use of a personal computer operating with relational database software to assist in analyzing data and supporting the decision making process. A DSS typically consists of a computer for providing the storage capacity and speed of operation for analyzing large volumes of data in a relatively short period of time and a relational database for providing versatile analysis capability with a user interface menu for choosing analysis options.

This report describes the concept, design, and application of a DSS for assisting in the Civil Works O\&M budget development at the HQUSACE and Division level of the Corps of Engineers. The DSS design was created through an iterative design process, including a needs assessment phase, a prototype test and evaluation phase, and field trials.

\section{Objective}

The overall objective of this work was to develop decision support capability within the O\&M budget process for assisting operations and programming managers in determining criteria by which projects can be evaluated for funds allocation within the budget process. The project approach was threefold:

a. Determine where the development of a DSS would be most beneficial within the budget process through a needs assessment survey.

b. Develop a working prototype through an iterative test and evaluation process, working closely with the potential system user.

c. Implement a fully operational DSS within an actual budget generation process and evaluate its effectiveness.

\section{Approach}

This work was originally directed to support operations managers at HQUSACE. During the needs assessment phase of the work, it was determined that enhanced data analysis tools were needed at the HQUSACE level to assist in evaluating the budget packages uploaded from the field offices.

Interviews were conducted with key personnel in the Operations, Construction, and Readiness Division, HQUSACE, to determine how the budget process was structured at the Headquarters level, and what types of analysis tools 
were needed. Interviews were held with supervisory staff (the Assistant Chief of the Operations, Construction, and Readiness Division, and Chief of the Operations Branch) to determine what factors, both external and internal, influence budget construction and data analysis needs. This provided information on how the budget process works at the national level, i.e., the funding constraints of the Presidential Budget and the influence of the OMB in the process of deciding how the funding will be allocated. It was revealed that the immediate need was for a more efficient method of evaluating funding scenarios based on "what if" situations posed by budget analysts or OMB. In the past, these scenarios were generated on the mainframe database, using the database SQL. This method was time consuming and tedious; thus the number of scenario analyses possible within the budget formation time constraints were limited.

Additional needs included a better method to rank work functions for funding, and to provide a financial reporting capability to show the breakout of funds given a funding scenario. Based on the results of the needs assessment, a prototype DSS was designed around a personal computer and commercial database software. A design team was organized with input from three USACE organizations and consultants from industry. The HQUSACE DSS was developed and tested during the Fiscal Year (FY) 1994 budget cycle. Based on the promising results obtained from the prototype tests, a Division level DSS was designed and implemented at the Ohio River Division, USACE, for the FY95 budget cycle. The Division level system was also conceptualized, designed, and tested in an iterative fashion, much like the HQUSACE application. 


\section{Civil Works O\&M Budget Process}

The objective of the O\&M program is to operate and maintain a large inventory of navigation, flood control, and multipurpose projects as long as they remain economically justified within budgetary constraints and consistent with current national priorities.

The yearly budget for Civil Works project O\&M is developed through the ABS and administered by HQUSACE. The guidance for budget development and submission is provided by an annual Civil Works budget Engineer Circular (EC) 11-2-157 (Headquarters, U.S. Army Corps of Engineers 1990), which is updated yearly. This publication provides guidance for funding all operation and maintenance activities under the appropriation tilles O\&M General, Flood Control, and Mississippi River and Tributaries for the budget fiscal year.

HQUSACE provides a target level of funding for each Division on the basis of a ceiling provided by OMB for the O\&M General appropriations account. This is the target funding level that each Division must meet in their budget request. HQUSACE provides a matrix table that describes the level of funding required for each work function category considered. Generally, five levels of funding are available for each work function category. These levels correspond to funding priorities ranging from routine and ordinary maintenance to meet state or federal mission and standards (level 1) to levels which are for additions and betterments in the outyears beyond the budget year. The baseline funding provided by the Presidential Budget is equivalent to level 2 funding. Level 3 funding is considered the O\&M effort consistent with normal and customary operation of project features at a cost approximately that of the previous budget year. Levels 4 and 5 funding are the first and second enhancement levels beyond the current level and provide for additions and betterments to enhance project facilities and to meet their demands and full authorized purposes.

The budget process is a transitory process which undergoes alterations from year to year. The above description of how the budget is generally constructed was for the budget year when this study was conducted (FY93 budget year). Changes to the budget are documented in updated EC 11-2-157. 


\section{Automated Budget System Design}

The task of managing O\&M budget information such as work packages is aided by the $\mathrm{ABS}$, a micro-computer based data management system. This system is used at the Division and District levels to collect, edit, prepare reports from, and otherwise manage, the budget work package data. The ABS was developed by the U.S. Army Construction Engineering Research Laboratory (CERL). This system consists of a database residing on a mainframe computer which is accessed by all of the Corps of Engineer field offices for budget preparation. The District and Division budget database are developed through the use of the ABS, and uploaded to HQUSACE for final preparation. Work functions are grouped or ranked according to criticality first by the District offices and then reviewed and re-ranked by the Division offices before being uploaded to HQUSACE for final ranking. The budget programmers access the mainframe database to run standard budget reports, rank the work functions, and perform limited budget analysis through the database SQL. A more specific deseription of the ABS is available from the ABS manuals for the District and Division offices and EC 11-8-2 describing budget submission requirements (Construction Engineering Research Laboratory, No. I; Construction Engineering Research Laboratory, No. II; Headquarters, U.S. Army Corps of Engineers 1991).

\section{District Budget Procedures}

The Corps of Engineer District offices prepare work packages for their $O \& M$ projects through the ABS. They use the guidance provided in the budget circulars for determining the funding level of the work categories and subsequent work functions within the categories. The goal of the District effort is to budget the funds to properly operate and maintain the projects for the budget year, and rank the projects on a priority basis.

Division managers review the previous year's O\&M funding request and begin assembling work packages for execution 2 years beyond the current budget year. The data call is extended to the project site level to provide the necessary data for constructing the work packages. A combined listing of the work packages is then put together, and a review process begins. Representatives from the functional divisions of the District, i.e., engineering, planning, etc., review the work packages and rank the work packages for funding.

At the District level, work function rankings are based on the projected adverse impact on the project if complete funding is not available. The criteria considered in the ranking process are customer service, reasonable user needs, minor and ordinary repairs, increased maintenance to ensure adequacy and integrity of structures, public safety, impact on the economy, environmental concerns, and national security. When the District budget is approved, it is uploaded through the ABS to the Division for approval. 


\section{Division Budget Procedures}

The uploaded District database work packages are then reviewed by programming, operations, and representatives from supporting elements within the Division. The review committee consists of individuals representing the various types of O\&M projects: navigation, hydropower, recreation, and flood control. These individuals have the experience and expertise to provide insight into the O\&M needs of the projects, and, subsequently, the funding levels required to maintain a high level of project operation. Prior years' funding is taken into consideration, as well as future project requirements, when reviewing the work packages. The Division reviews the project rankings provided by the Districts. Consideration must be given to the work function rankings from all of the Districts before assigning a Division ranking. The Division not only evaluates the District rankings on similar criteria as the District, but also in a broader sense, with consideration given to the impact of project funding on the region as well. Because of this broader view of project/work function priorities, the Division and District rankings frequently differ. After the Division committee reviews the work packages, their questions and recommendations are relayed back to the District. The District then addresses the concerns of the Division and makes revised corrections to the District database for up-load to HQUSACE. The Division database is then established, and Division ranks assigned to work functions on a priority basis are uploaded through the ABS to HQUSACE. Any work function corrections made after formation of the Division database are a Division responsibility.

\section{HQUSACE Budget Procedures}

HQUSACE is responsible for reviewing budget submissions from 11 Divisions consisting of a total of 33 Districts. Approximately 20,000 work functions múst be reviewed and given a final rank for funding. These ranks must consider the same criteria as the Division and District ranks, but at the national level. Certain projects at the District/Division level will have a greater impact nationally than others. For example, dredging on the Mississippi River is essential for keeping the river channel navigable for the transport of cargo from a significant portion of the United States. It is essential to the national economy that the river remain open. On the other hand, a localized District administered project may be a high priority to the adjacent area or region, but not critical to national interests, and not be as high a funding priority at the HQUSACE level. Therefore the rankings at the Districh, Division, and HQUSACE levels will often be dramatically different. 


\section{O\&M Budget Analysis Needs}

The task of managing the O\&M budget information is aided by the use of the ABS. While the ABS functions adequately in assimilating budget data at the field level, it is limited in providing decision support capability. The current structure of the ABS data, the limitations of the network model, and the Iack of analytical tools within the existing database management system make it difficult to make queries, cross-tabulations, and other statistical analyses that are needed to make decisions concerning the budget. The ABS does not provide the tools that can assist managers in investigating project options and alternatives. There is no ability to quickly generate "what-if" options to examine the consequences of different work function rankings or cutoff funding levels. Another deficiency of the ABS database is the loss of information as budgeting decisions are made throughout the budget generation process in the field. As the decision level proceeds up the hierarchy, much of the knowledge about what went into the professional judgment at each lower level is lost.

A variety of database analysis capabilities are needed at all levels of Civil Works O\&M to support the budget process. Database flexibility is required for performing data manipulations to support budget generation activities such as project rank compilation, funding scenario analyses, and financial analyses.

Interviews were held with personnel of the Operations, Construction, and Readiness Division, HQUSACE, to identify potential DSS applications for supporting the O\&M budget process. A major concern of O\&M managers was the ability of budget analysts to evaluate all of the budget data and rank the numerous work functions within the time allotted for budget development. The field offices upload the budget packages via the ABS using a mainframe database. During past budget development efforts, budget analysts at HQUSACE accessed the database and performed database operations while connected to the mainframe. The process in which the data were evaluated, and work functions eventually ranked, was tedious and time consuming as well as expensive due to the mainframe computer operation cost. The only analysis tool available to the budget analyst for sorting the database and producing reports was the SQL available on the mainframe database. 
It is essential that all alternative funding scenarios be examined before final work function ranks are assigned. Of particular importance are funding scenarios which involve work functions that may be within the vicinity of the funding cutoff line. It is critical that HQUSACE evaluate work functions at this level to ensure that all $O \& M$ objectives are optimized.

A scenario, as defined by the budget application, is a data evaluation involving one or more work functions. For example, it may be necessary to query the database for the highest cost dredging work function in the Lower Mississippi Valley Division (LMVD). The desired result might be a report showing the work function name, the funding level, the District that it resides in, and the total dollars. A scenario involving numerous work functions may be a query for all of the level 2 work functions with a cost greater than \$1 million. The report generated would list the work functions by Division, District, and the total dollars. Another potential work function ranking scenario may be the effect of a reduction of funds on the ranking of projects around the cutoff line, i.e., which projects would be funded, which would not be funded, and what does the new rank look like. For example, if a class of projects, such as low use recreational areas, are cut from the budget, a data report may be desired that describes what previously funded projects will be cut, in which Divisions and Districts they reside, what the total costs are, and what the new rank looks like after the projects are taken out. These are just a few examples of the numerous analysis options that HQUSACE requires for evaluating the budget. Essentially, HQUSACE had three initial main requirements for the development of a budget analysis DSS: (a) the system must be capable of operating independent of the mainframe computer but capable of communication with the mainframe, (b) the system must be capable of generating and storing scenarios through a menu driven interface, and (c) the DSS must be capable of producing the analysis and subsequent reports with a reasonable process time.

In response to the needs of HQUSACE for enhanced budget analysis capability, a DSS design team consisting of members from U.S. Army Engineer Waterways Experiment Station (WES), CERL, Institute of Water Resources (IWR), and industry consultants developed a prototype budget DSS. The prototype was developed in an iterative test and evaluation process in a cooperative effort with budget analysts from HQUSACE. 


\section{Budget DSS Prototype Design, HQUSACE Level}

In the initial developmental phase, the system software and hardware requirements were determined. The DSS, now named the Corps of Engineers Operations and Maintenance Budget Decision Support System (COMB_DSS), was designed for a 386 personal computer or better, using the DOS operating system. The COMB_DSS prototype was built around a commercially available database, $\mathrm{R}: \mathrm{BASE}$, and custom software written in $\mathrm{C}$ programming language.

Based on the needs assessment phase of the project, three primary capabilities were built into the prototype DSS: a scenario analyst for creating funding scenarios, a financial analyst for breaking out the costs associated with a scenario, and a rank generator for ranking work functions.

The key database table in the COMB_DSS is the work function table which contains information on each of the individual work functions, including District, Division, Civil Works Investigation Studies (CWIS) number, District and Division rank, initial HQUSACE rank, work function descriptions, project class, and feature cost code. This table is downloaded from the mainframe database into the COMB_DSS. Information in this table is not permanently changed until the final assignment of revised ranks by HQUSACE.

\section{Scenario Analyst}

Three types of scenario analyses were designed. A primary scenario is the selection of work functions by relating them to a defined set of criteria, for example, all work functions in level 2 funding with funding requirements greater that \$1 million. A composite scenario relates the work functions contained in multiple primary scenarios. This option would be used to determine which work functions are common to two or more separate primary scenarios. An $S Q L$ scenario is generated using the database SQL to generate a user-defined query to the work function table to create a scenario. The capability for building the first two scenarios (primary and composite) are 
provided from a menu-oriented user interface. The SQL is a manual method of querying the work function table in the database.

The COMB DSS contains a menu-driven user interface for choosing or building scenarios. The main menu for the COMB_DSS contains the scenario analysis options available. A manage scenarios menu is provided for entering, editing, copying, deleting and renaming scenarios. A run scenarios menu is used for actually building, executing, and evaluating the scenario. Appendix A contains an example of the scenario analysis capability of the COMB_DSS.

\section{Financial Analyst}

The financial analyst was designed to provide work function cost breakouts at three levels: at the overall scenario level (Corps wide), detailed costs within a division, and by work function within a scenario. The first two levels allow for comparison of up to seven scenarios, with cost breakouts by Division, Feature Cost Code, and by Project Class. This was designed to provide information on the distribution of costs due to potential funding impacts.

\section{Rank Generator}

In the past, work function ranking at the HQUSACE level was performed by assigning ranks to work functions based on evaluations by budget personnel of the District and Division ranks. The ranking approach taken by the COMB_DSS prototype was to priority rank the work functions at the scenario level. Funding scenarios were ranked in order of importance. The scenario rank therefore indicates the ranking priority of the work functions that are included within it. If a work function is in more than one scenario, it is assigned the rank of the highest ranked scenario that it is in. 


\section{DSS Prototype Test and Evaluation, HQUSACE Level}

Overall, six prototypes were developed and evaluated in a cooperative effort with budget analysts at HQUSACE. The final prototype was applied to the FY94 budget year analysis beginning July 1992 . The COMB_DSS resided on a $486 / 50 \mathrm{Mhz}$ computer. The personal computer communication with the mainframe database was accomplished by the Transmission Control Protocol/Internet Protocol (TCP/IP) inherent in File Transfer Protocol (FTP) version 2.0.5. The Civil Works O\&M budget database residing on the mainframe computer was accessed and extracted using the RAMIS relational database management system. The size of the budget database resident on the mainframe computer was approximately $22 \mathrm{MB}$.

The results of the COMB_DSS implementation at HQUSACE were positive. Approximately three times as many funding scenarios were performed as in previous years, without the additional cost of the mainframe computer time. The transmission of data from the mainframe computer to and from the personal computer went smoothly, without causing any substantial delays. The COMB_DSS provided a more cost effective alternative to the manual queries used previously to generate scenarios on the mainframe. More information on the HQUSACE DSS development can be found in Strus et al. (1994). 


\section{DSS Prototype Design, Division Level}

Due to the success of the HQUSACE prototype, it was decided by the development team and HQUSACE to implement a version of the COMB_DSS at the Division level to provide enhanced budget data analysis/decision capability. The Ohio River Division (ORD) was chosen for the design and implementation of the Division DSS, now referred to as the COMB_DSS_D. ORD has responsibility for the administration of projects within four Districts-Louisville, Pittsburgh, Nashville, and Huntington. Approximately 3600 work functions are submitted in the O\&M budget for the districts.

Because the budget submittal and analysis process is somewhat similar for HQUSACE and the Division, the COMB_DSS served as a first prototype, to be altered based on Division needs. The same conceptual approach was taken for the Division application. Interviews were conducted with key Budget personnel within the ORD Construction Operations and Readiness Division. Six desired system capabilities were identified during the interviews: (a) report generation, (b) quality assurance checks, (c) scenario analyses, (d) division ranking, (e) impact analyses, and (f) data transfer to and from the ABS.

\section{Report Generator}

The capability to generate custom standard reports was incorporated into the system. In the past, the Division had used a combination of spreadsheet and database software to produce the reports. The COMB_DSS_D utilized a selection criteria data entry form to choose the type of report desired. The reports could be chosen based on the following set of criteria: division rank ranges, funding level, feature cost code ranges, work function count, and appropriation code.

\section{Quality Assurance Checks}

This system capability was developed for checking all of the data records 
under the work functions to ensure the data were valid. For example, the system checks for missing data such as CWIS numbers, ranks, category codes, or feature cost codes. The Division required this capability during the Division review of the District database.

\section{Scenario and Financial Analyst}

The scenario and financial analysis capabilities available from the HQUSACE version were incorporated into the Division version.

\section{Division Ranking}

The scenario ranking procedure used in the HQUSACE version did not meet the needs at the Division level. ORD automatically ranks the level 1 work functions, and then manually ranks the level 2 work functions through waivers in a meeting with District and Division personnel. Each work function is evaluated and prioritized, and eventually given a Division rank. With the additional analysis capabilities provided by the COMB_DSS_D, additional capability was added for prioritizing the work function rank. A data entry menu allowed the user to enter a Division rank, which brought up a corresponding work function record. The user was then able to edit the record, save it, and enter another Division rank for a new rank assignment. The result was a table with the final work function rankings. Three other ranking options were built into the COMB_DSS_D, but were not used as frequently during the ranking process.

\section{Impact Analyst}

ORD was concerned about the effect of funding allocation changes made at the HQUSACE and OMB levels during the budget review process. They indicated that it was difficult to discern the changes made in the Division budget packages, particularly changes in the cost of work functions, or which work functions were changed from a funded to an unfunded status. A limited impact analysis capability was provided by the COMB_DSS_D which allowed the user to compare the total cost, by work function, with the revised cost after the work package had been through the HQUSACE/OMB review. The impact analysis option was not considered a major need, and was not developed beyond this limited capability.

\section{Data Transfers}

Data transfer capability was developed to facilitate the passage of data from the Division ABS to the COMB_DSS_D and to return the data back to the 
ABS after analysis. The data transfer process of the budget cycle begins when the Districts upload their work packages to a mainframe computer through the ABS. The Divisions access the mainframe, and download the work packages for review. After the Division reviews the packages and creates a Division database, they are uploaded back to the mainframe, and eventually accessed by HQUSACE. The COMB_DSS_D must download the budget database from the Division personal computer, and return it after analysis. Software was written to read in the ABS database tables and create an output table compatible with the COMB_DSS_D. 


\section{DSS Prototype Test and Evaluation, Division Level}

Three versions of the COMB_DSS_D prototype were developed by the design team with cooperation of ORD budget analysts. The system was tested July 1993 during the budget submittal process for the FY95 O\&M budget. The COMB_DSS_D was installed on a $386 / 25 \mathrm{Mhz}$ personal computer which was connected through a local area network to the mainframe computer located at WES where the ABS database resides.

The Division initially used the quality control component of the COMB_DSS_D to ensure the work function data fields were correct. The system worked as designed, performing logical checks of the data fields and indicating when there was a problem with the database.

The scenario analysis tool was used primarily to generate financial reports on subsets of work function data. Four primary scenarios were builh, one for each District (Huntington, Louisville, Nashville, and Pittsburgh). These scenarios were used to generate a feature cost code financial report, which provided total dollars by feature cost code and District. Guidance from HQUSACE required that operations was to comprise 75 percent of the funding and maintenance comprise 25 percent. Scenarios were generated for each District based on this limiting criteria. The Division used the scenario results to assess how closely the Districts adhered to the guidance.

The COMB_DSS_D was successfully implemented at the Division. The system capabilities were all used to some degree to assist in the budget data analysis. Personnel responsible for budget preparation worked closely with the design team in both the design and implementation phase. The prototype was frequently modified as needs arose during the data analysis and ranking stages of budget development. More information on the Division DSS application can be found in IWR (1993). 


\section{Summary}

A DSS was developed for assisting in Civil Works O\&M budget data analysis. Funding for system development was provided through the IOMT research program, administered by HQUSACE. A design team consisting of members from IWR, WES, and CERL, along with industry consultants, developed prototype systems for application at HQUSACE and the Ohio River Division of the Corps of Engineers.

The system was developed in the following phases: a needs assessment phase where the O\&M budget preparation procedures were examined and DSS applications were determined, a conceptualization phase where the prototype structure was first constructed, an iterative design phase where the user evaluated the prototype and suggested system re-design, and a test and evaluation phase where the DSS was implemented and evaluated during an actual budget preparation and review. Both the HQUSACE and Division applications were based on a work function scenario analysis capability which provided the user with a tool for comparing and prioritizing work functions within the O\&M budget.

Scenario analysis, financial reporting, and ranking analysis were the three primary uses of the DSS at both levels. The HQUSACE prototype, COMB_DSS, was successfully implemented during the FY 94 budget year preparation. Six prototype versions were built following an iterative design and test plan. Budget analysts were able to run three times as many funding scenarios as in previous years, without the additional costs of the mainframe computer previously generated during the scenario analysis.

The Division prototype, COMB_DSS_D, was implemented at the Ohio River Division during the FY95 budget year preparation. This prototype design contained many of the features of the HQUSACE prototype, with additional options added to meet Division needs. Three prototype versions were built in cooperation with ORD budget analysts. During implementation, the COMB_DSS_D proved particularly useful for providing financial work function summaries for the Districts, quality control capability for checking the District database for completeness, and a systematic method for assisting in the ranking of work functions. 


\section{Conclusions}

The successful design and implementation of DSS's within any decision making environment are dependent on a close working relationship between the system designer and potential user. The hardware and software necessary for creating a user-friendly computer-based system are readily available. The developmental problems are mainly due to problem definition and fulfilling user needs. It is imperative that the decision making environment be defined as completely as possible before beginning prototype development and evaluation.

The HQUSACE application provided ideal conditions for the development effort. One user was primarily responsible for supervising the budget data analysis process, and was readily available for consulting with the design team. The user provided a concise definition of what type of analysis tools were needed, how they should be structured within the overall system, and the type of system output required. The needs assessment phase of the HQUSACE application was instrumental in defining the $O \& M$ budget process, the analysis needs, and the initial hardware and software design requirements. Previous years' budget data were available for performing system test and evaluation for each prototype design.

The Division DSS prototype development presented more of a challenge to the design team. Although potential users within the Division worked closely with the design team, unlike the HQUSACE application, the users had no predefined need before the development process began. The design team discussed the HQUSACE prototype with the Division, and assisted in defining the analysis tools that might be needed at the Division level. During the implementation of the DSS within the actual budget process, additional analysis needs became apparent to the user, requiring numerous alterations to the prototype.

Both applications, HQUSACE and Division, were successful in that they proved that the DSS concept can provide additional budget analysis capabilities. Both applications, particularly the Division application, revealed the need for extensive training on the use of the system. Although the DSS concept potentially is a much more efficient way to retrieve and analyze data, it must also be a system that the user is comfortable with and readily understands. A training manual should accompany any DSS tool to ensure 
that the user will adapt the system and use it to its fullest capability. At the time of this writing, both the HQUSACE and Division versions are being refined and adapted into the budget process. 


\section{References}

Construction Engineering Research Laboratory. "Automated Budget System Manual - No. I (District), " Champaign, IL.

Construction Engineering Research Laboratory. "Automated Budget System Manual - No. II (Division)," Champaign, IL.

Headquarters, U.S. Army Corps of Engineers. (1990 Mar). "Annual Program and Budget Request for Civil Works Activities, Corps of Engineers, FY 1992," Engineer Circular No. 11-2-157, Washington, DC.

Headquarters, U.S. Army Corps of Engineers. (1991 Mar). "Submission Requirements," Engineer Circular No. 11-8-2, Washington, DC.

Institute of Water Resources. (1993). "Corps of Engineers Operation and Maintenance Budget Decision Support System, Division Prototype (COMB_DSS_D)," IWR Report 93-R-15, Fort Belvoir, VA.

Strus, Craig A., Robinson, Russ E., Males, Richard M., Walsh, Michael R., Raaymakers, Connie L., and Japel, Edward J. (1994). "Corps of Engineers Operations and Maintenance Budget Decision Support System (COMB_DSS): System concept, design, and prototype evaluation," Volumes I and II, Contract Report HL-94-1, prepared for U.S. Army Engineer Waterways Experiment Station, Vicksburg, MS. 


\section{Appendix A Example of COMB_DSS Scenario Generation}

The COMB_DSS was primarily designed to provide the capability to analyze work function budget data and present it in report form to the user. The O\&M budget data for all eleven Divisions are downloaded from the mainframe computer to the DSS for analysis on the personal computer. The DSS contains two primary capabilities for analyzing work functions:

(a) analysis of work functions according to the funding rank and (b) cost analysis of work functions according to Division, Project Class, Project, and Feature Cost Code (FCCD). The analysis capabilities are presented through a menu which presents the analysis options to the user in a direct step-by-step manner.

\section{Operating Menus}

Two main menus are used to create and execute the work function analysis options. The "manage" scenarios menu is used to create or edil a work function scenario, and the "run" scenarios menu is used to execute and evaluate the scenario. The menus are designed to take the user through each step of building, editing, executing, and evaluating the work function scenario. Attachment 1 is an outline of the steps necessary for entering, executing and evaluating a work function scenario. Attachment la shows the options available under the Manage and Run Scenarios menus. Attachment $1 \mathrm{~b}$ shows how to build a scenario using the enter/edit/clone primary scenario option on the Manage Scenario menu. The data input tables appear on the bottom. Attachment $1 \mathrm{c}$ shows how to compile and run a scenario from the Run Scenario menu.

\section{Work Function Analysis by Rank}

Each work function in the database contains an HQUSACE funding rank. In the database, these rankings are depicted in a seven-digit format. For 
example, a funding level 1 ranking is shown as 1000520 , with the "1" representing the funding level, and the work function rank being 520 . The level 2 work functions are specified as 2000000 , the level 3 as 3000000 , and so on. The following examples will show the utility of the DSS in analyzing the work function data.

\section{Example 1: Analysis of all Level 1 work functions}

To analyze the Level 1 work functions, data are input from the Manage Scenarios menu. Input data required are: (a) scenario name; (b) appropriation code (O\&M General (C), Construction General (E), or Mississippi River and Tributaries (F)); (c) the range of HQUSACE ranks; and (d) the desired format of the output report (by Division, FCCD, project class, project, or rank. For the level 1 example the following data are input:
a. Name - level 1
b. Appropriation Code - C (only O\&M projects)
c. OCE Ranks - $1000000-1999999$
d. Desired Output - By Division, Division and FCCD, project class, and Division and project ranking list

To execute the program, the Build Scenario option is chosen from the Run Scenario menu, and the scenario is compiled and evaluated. Attachment 2 is the data input table. Attachment $2 a$ is a summary output report showing examples of Division, Division and FCCD, project class, and a partial ranking list by Division and project.

\section{Example 2: Analysis of Special Recreation User Fee work functions for all Divisions}

The Special Recreation User Fee work functions are found under feature cost codes 606.3 and 629.9 . Therefore on the input menu, only these feature cost codes are selected for analysis. The following data are input:
a. Name - ALLSURF
b. Appropriation Code - C
c. OCE Ranks - (no input defaults to all work functions)
d. FCCD -606.3 and 629.9
e. Desired Output - by Division, FCCD, and a project summary 
The program is then compiled and evaluated through the Run Scenario menu. Attachment 3 is the data input table. Attachment $3 a$ shows the cost by Division, FCCD, and a partial project summary table.

\section{Example 3: Cut 100M from selected operations accounts from the baseline request}

The baseline request consists of funding levels 1 and 2 . For this analysis, the following data must be specified: OCE ranks, a cumulative dollar amount $(100 \mathrm{M})$ to delete above the baseline rank, and the operations feature cost codes (601-619). The following data are input:

a. Name - OPCUT100

b. Appropriation Code - C

c. OCE Ranks - $1000000-2800000$ (levels 1 through 2)

d. Cumulative Cost $-\$ 100,000,000$

e. FCCD - 601 through 619

f. Desired Output - Division, FCCD, and project FCCD summary

The program is compiled and evaluated through the Run Scenarios menu. Attachment 4 is the data input table. Attachment 4 a shows a partial output by Division, FCCD, and partial project FCCD summary. 
USER PATH FOR CREATING AND RUNNING WORK FUNCTION SCENARIOS

MANAGE SCENARIOS MENU:

- Create a scenario (enter in a scenario)

1. DATA INPUT TABLE

Specify:

scenario name

appropriation code (OSM, CG, MRET)

ranking range

range of costs (if needed)

division(s) output

project class(s) output

project(s) output

rank output

FCCD(s) output

RUN SCENARIOS MENU:

- Build a scenario - execute the program

- Evaluate a scenario

2. INPUT SCENARIO OUTPUT PARAMETERS

output by:

DIVISION - Cost totals by Division

PROJECT CLASS - Cost totals by project class FCCD - Cost totals by FCCD

DIVISION AND FCCD - FCCD totals by Division PROJECT SUMMARY - Project class, project, State, project name, cost

PROJECT AND FCCD - Project name, FCCD, FCCD description, total cost

RANKING LIST - By Division, project, OCE

Determine output device (screen or printer)

Print report 


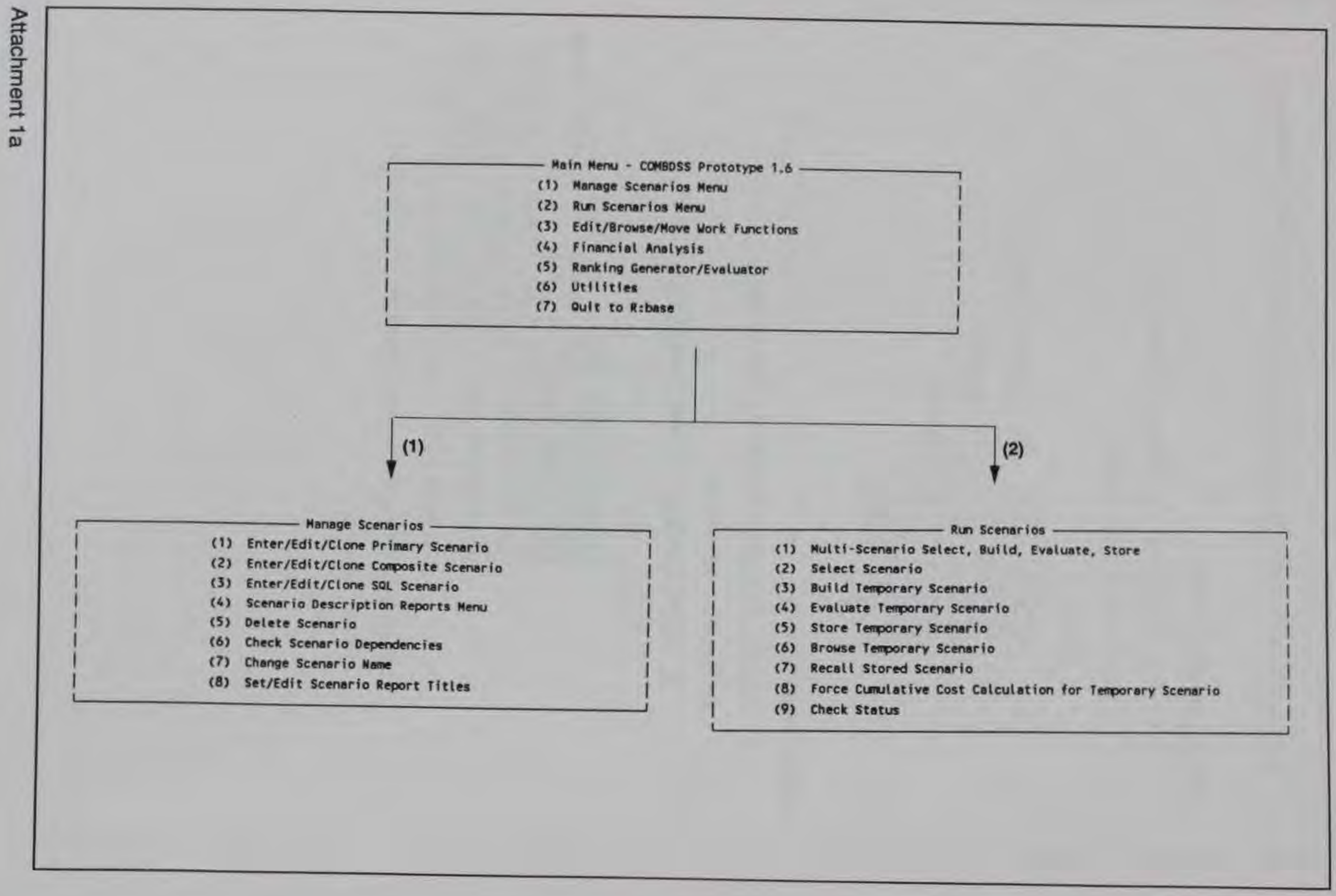




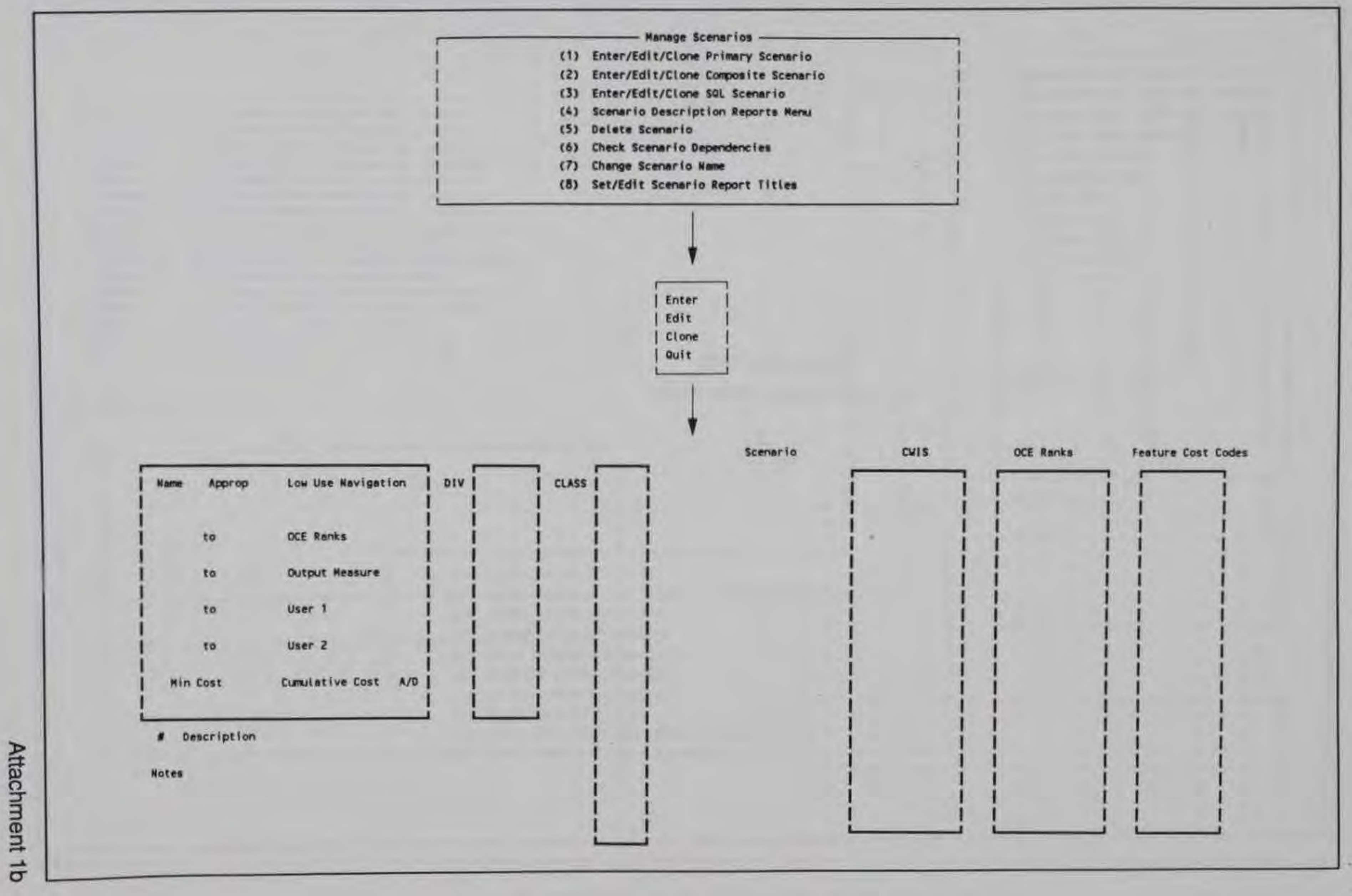




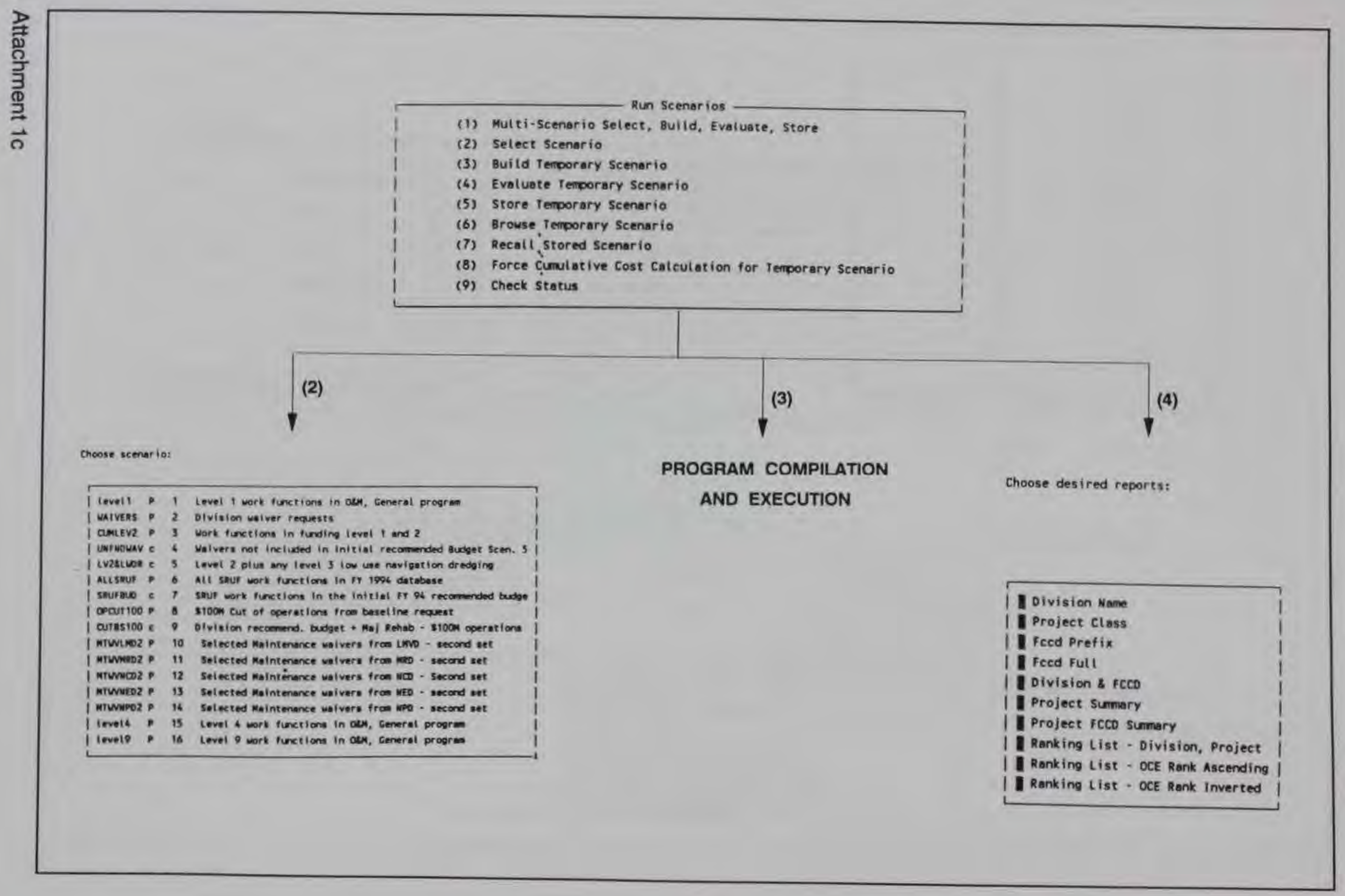




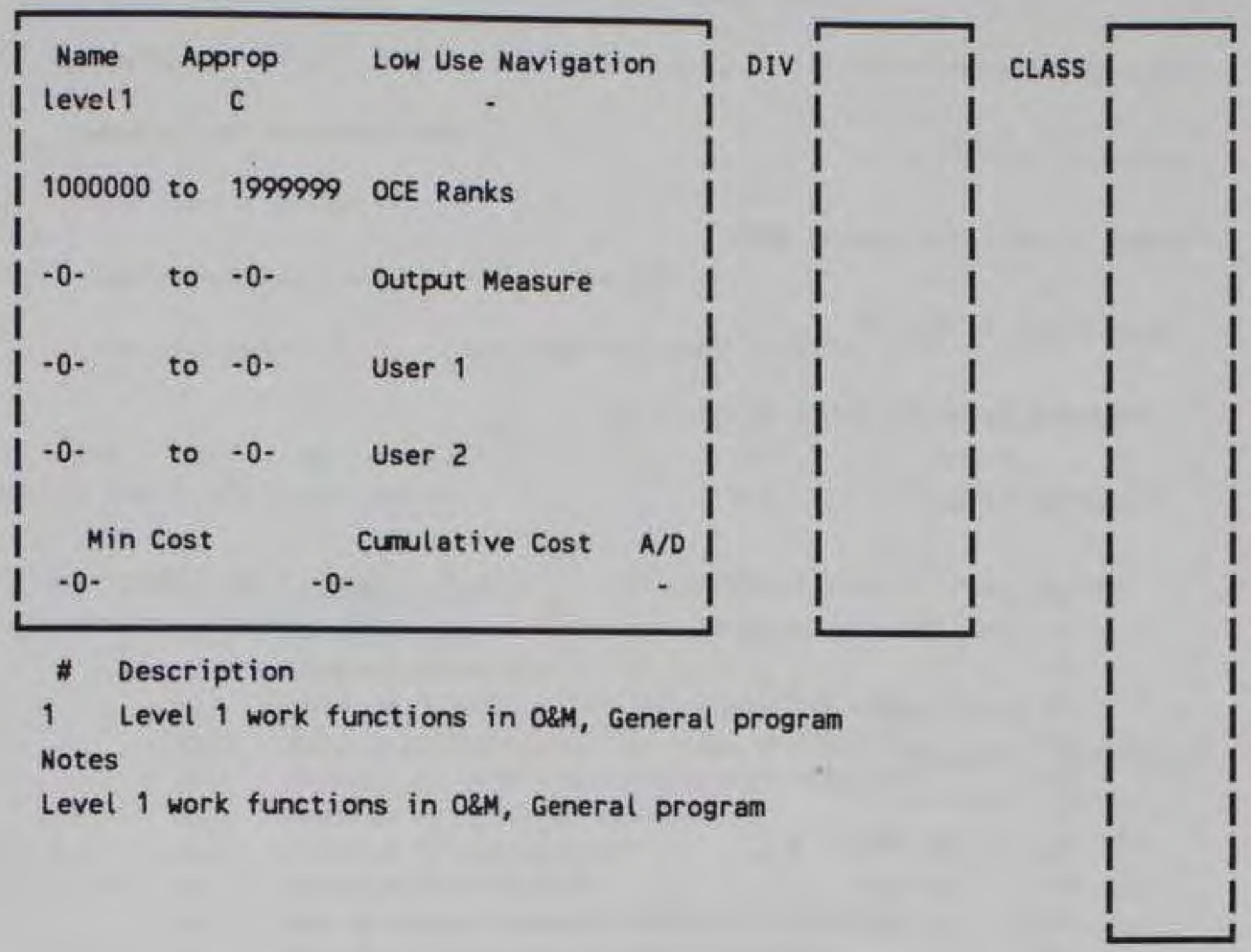

Scenario

CWIS

OCE Ranks

Feature Cost Codes

levell
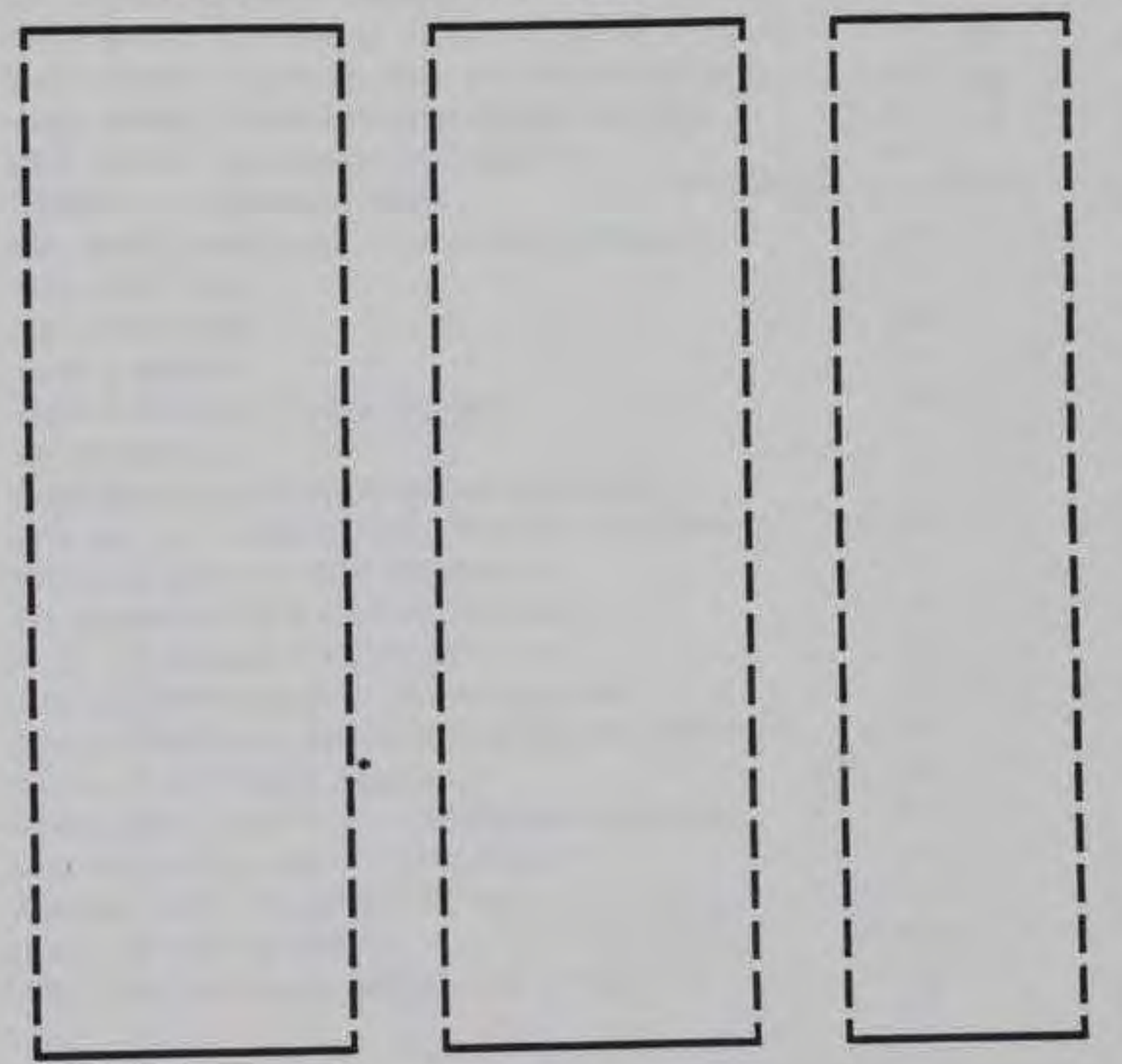

Attachment 2 


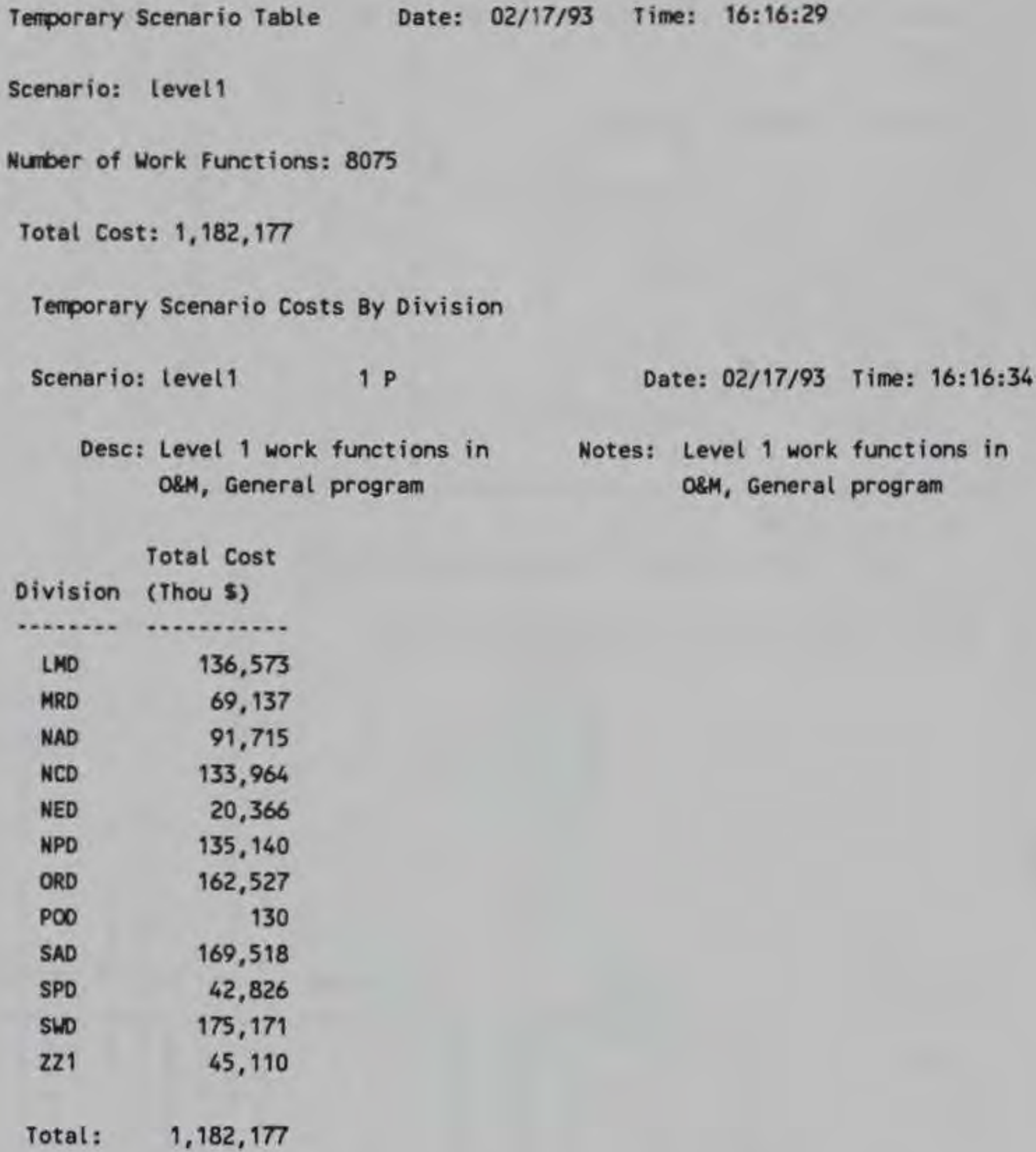




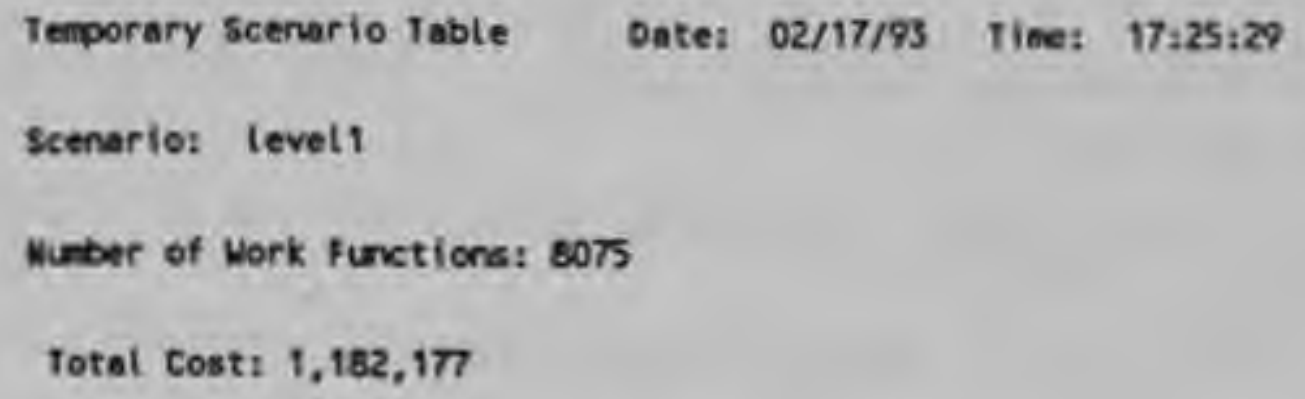

29.11 EWVIRONMENTAL CONPLIANCE - RECREATION MATWTENANCE 
30.2 MAINT. OF PERM OPER EQUIP-REGULAR

31 BANK STABILIZATION

32.1 MAINT. OF NON-RECREATIONAL BLDGS, GROUNDS AND UTI

33.11 DREDGING - NAVIGATION

33.21 NON-DREDGING NAVIG. CHANNEL MAINT., SNAGGING, CLE

33.22 MAINT, OF REVETMENTS, GROINS OR DIKES TO CONTROL.

33.3 DREDGED MATERIAL DISPOSAL FACILITY CONSTRUCT. AND 
Temporary Scenerio Table Date: 02/17/93 Time: 16:36:26

Scenario: level1

Number of Work Functions: 8075

Total Cost: $1,182,177$

Temporary Scenario Costs By Class

Scenario: level1

Date: $02 / 17 / 93$ Time: $16: 36: 30$

Proj Class Description
Class

Total Cost

(Thousand dollars)

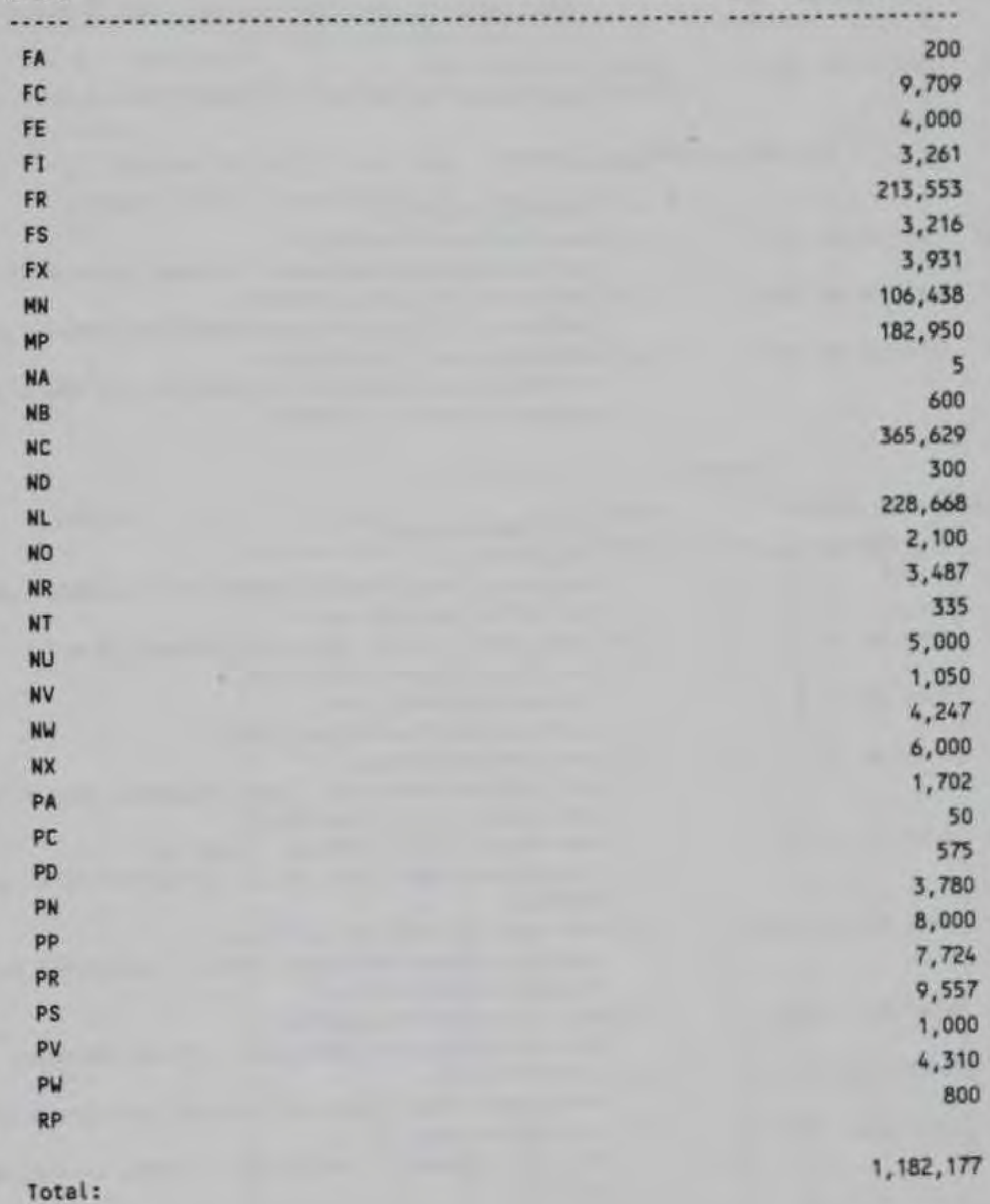




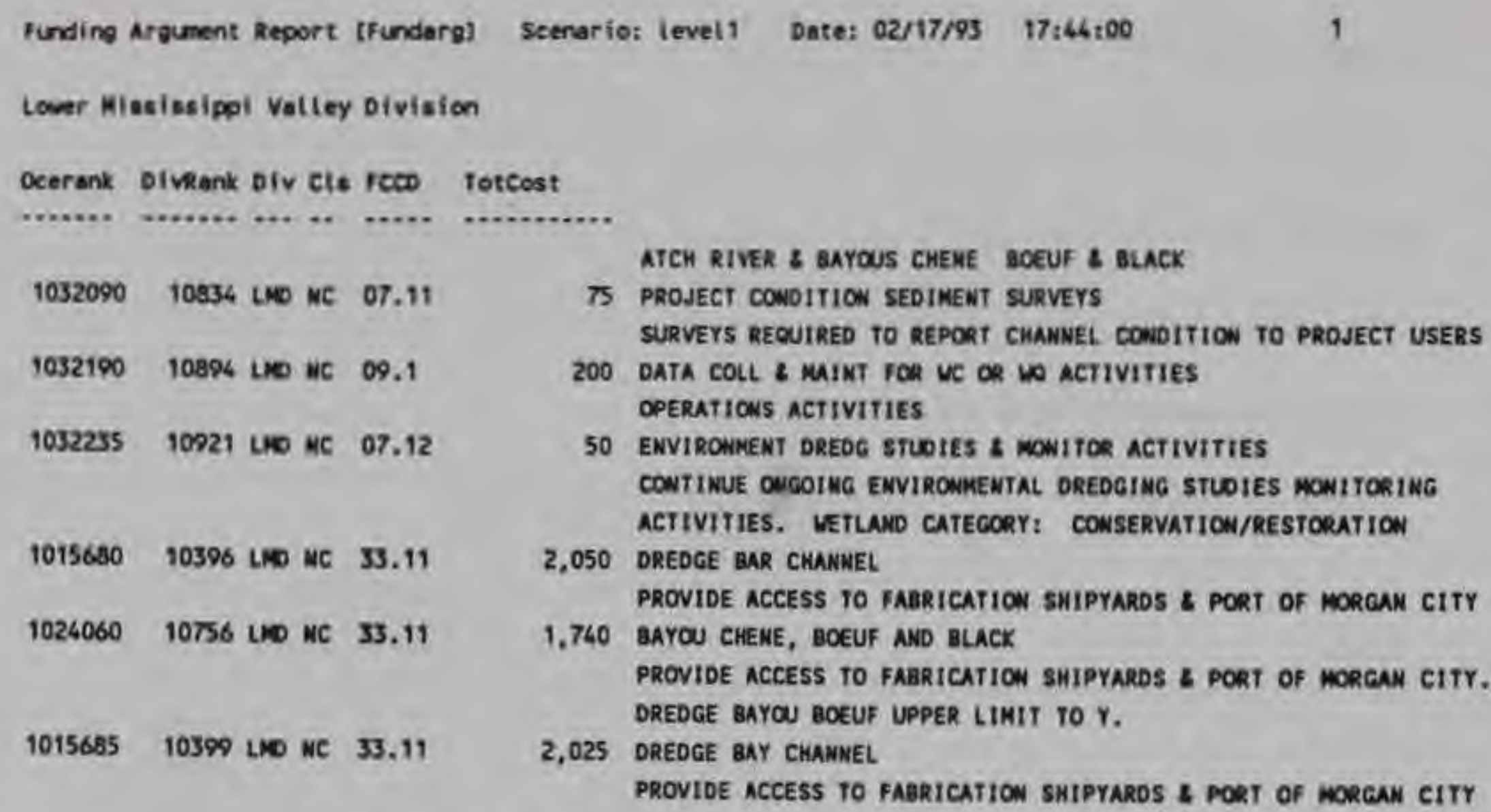

BAYOU BCOCAU RESERVOTR

3 TIMBER MARVEST WECESSARTY TO PROCESS SALE OF TIMBER UMICH UHLL PROVIDE GREATER THAN COST OF PROCESSING IN EY

9 MANAGT, COMPL., UTILL., IMSPECTIONS, DUTGRANTS 2 ALOITS COAPLIANCE/UTILIZATION IMSPECTIONS

6 CULTURAL RESCURCE INVENTORY INVENTORY FOR CRIYICAL PRIORITY AREAS

101 OPER OF RECREATIOW AREAS OPER \& PERFORH MINOR MUIMT IN REVENUE PRCOUCIMG AREAS TO MEET ONLY BASIC NEEOS OF TME VISITING PUBLIC

20 MUNACEMENT OF MATURAL RESOURCES - FOREST MGT PERFORM MINOR 2 ORDIM MAINT CRITICAL TO PRESERVATIOW OF MATURAL RESOURCES.

15 CONTIMUIKG EVALUATION OATA GATHERIMG ESSENTIAL GATMERING PROCESSIMG, PLOTTIMG, EVALLATION, $L$ REPCRTIMG OF ENGIMEERING MEASUREKENT DATA.

a OPER OF PERM OPERATING EQUIPMEMT OPERATE \& PERFORM MINOR MAIMTENAMCE TO PRONECT EQUIPMEMT

SO OPERATIOW OF DNM OPER OF DMM L MINOR RUINTEMANCE TO ASSURE FLOCD CONTROL CADABILITY

50 OPERATION OF RESERVOIR RESERVOIR MAIMTEMANCE \& SURVEILLAMCE TO ASSURE FLOCO COWTROL CAPABILITY 


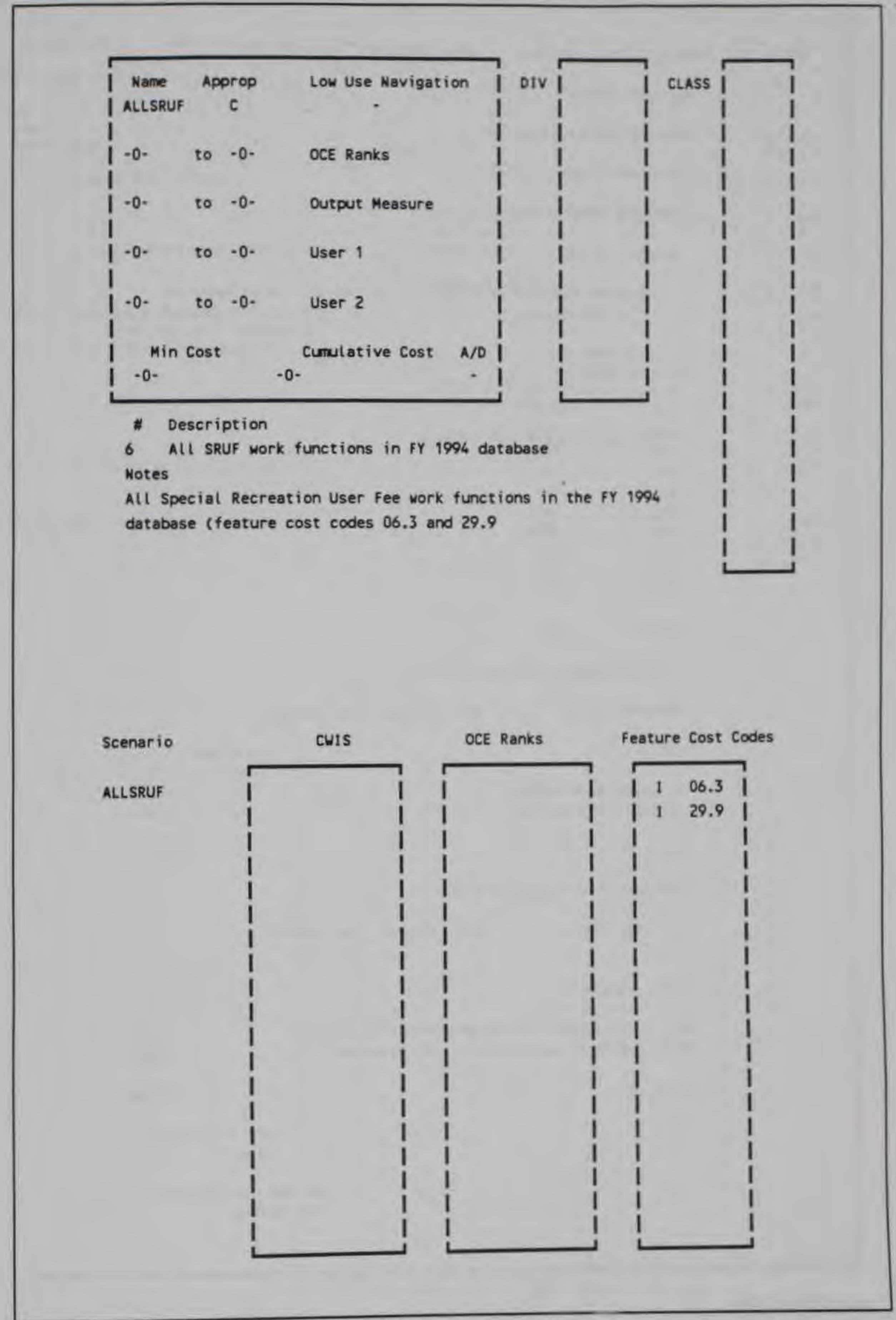




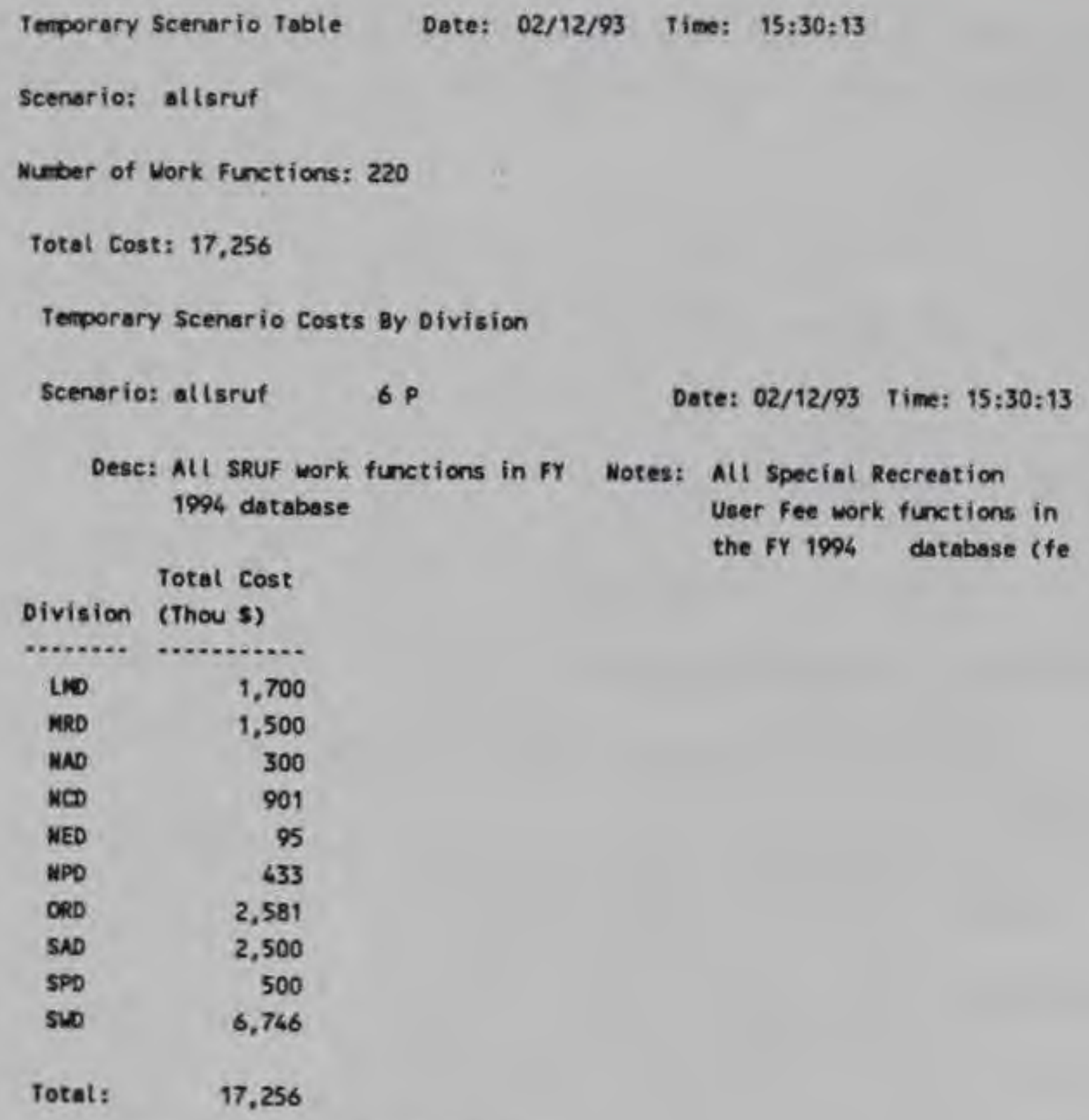

Total:

Temporary Scenerio Costs By FCCD

Scenario: allsruf

Date: 02/12/93 Time: 15:30:15

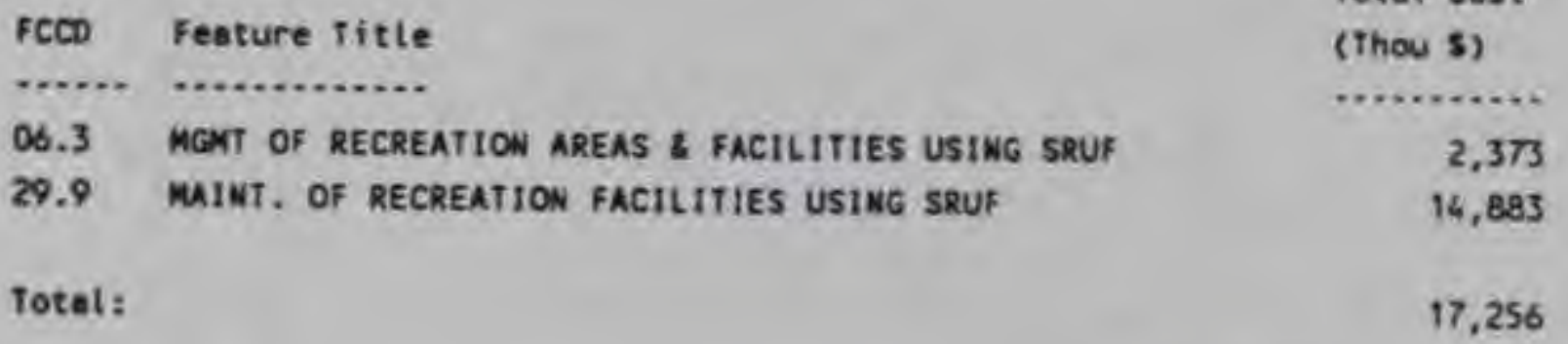


Lover Mississippi Valtey Division

Cat/

Class/

subclass class

Stote Project

Total cost

.......... ....

(Thou s)

210 FLOOO CONTROL - RESERVOTRS

CARLTLE LAKE II

LAKE SHELHYVILIE IL

REND LAXE II

no

UAPPAPELLO LUKE WO

SLbtotal FLOCO CONTROL - RESERVOIRS

AR

BLAKELY MT DAM-LAKE CUACHITA

10

CLARENCE CANOH DNA I MARX. TMAIN LAKE WO

Subtotal Lower Mississipoi Valley Division 

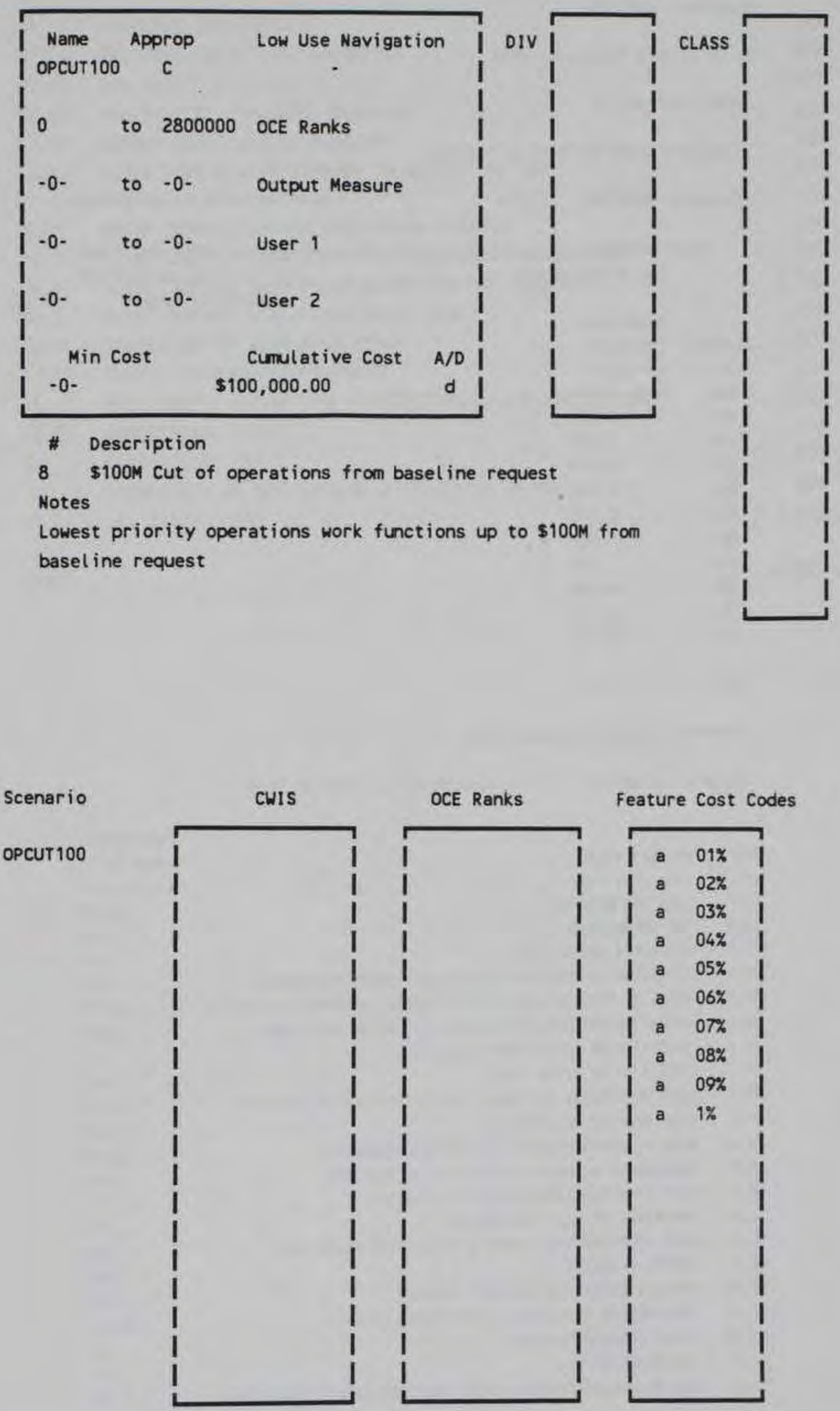

OCE Ranks

Feature Cost Codes

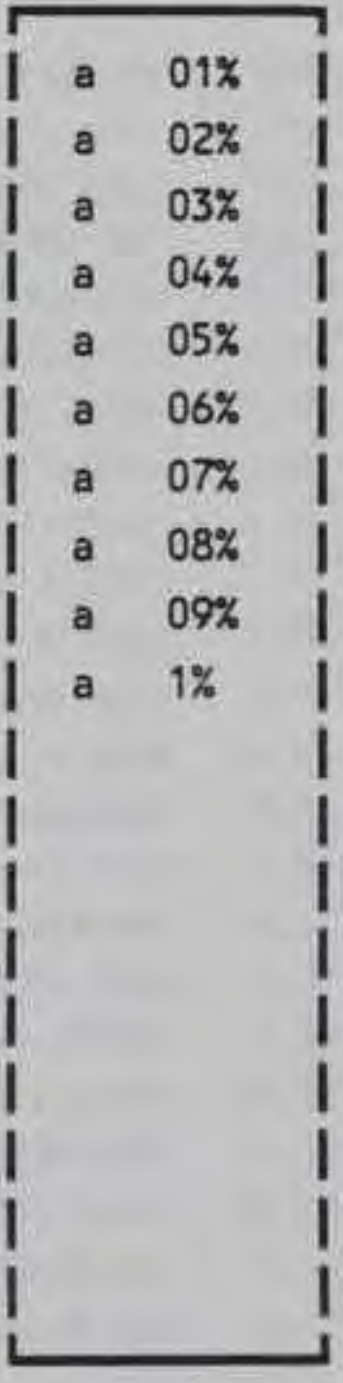




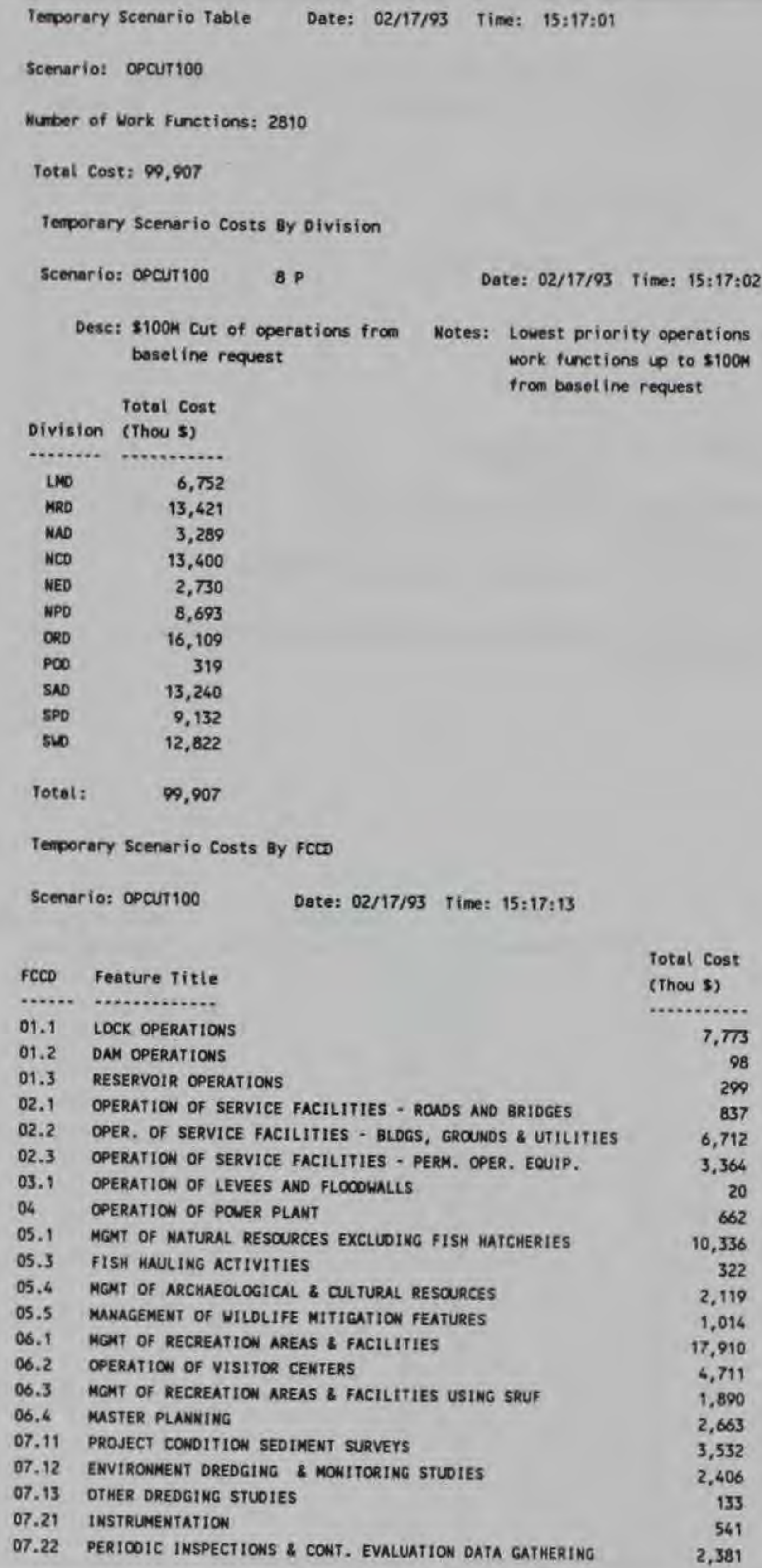


07.23 PERIOOIC INSPECTIONS

1,299

07.24 PERIOOIC INSPECTION REPORTING

07.41 DAM SAFETY STUDIES

1,435

07.42 DAM FAILURE EMERGENCY PLANNING

422

07.52 ENERGY CONSERVATION PROGRAM

198

07.53 OTHER COND \& OPER STUDIES IN SUPPORT OF OSM

4,229

07.6 HYDRAULIC MOOEL STUDIES

32

07.7 MAJOR REHABILITATION EVALUATION REPORTS

440

09.1 WATER CONTROL MANAGEMENT-DATA COLLECTION\&PROCESSING

1,300

09.2 WATER CONTROL MANAGEMENT-HATER CONTROL ANALYSIS

2,185

09.3 HATER CONTROL MANAGEMENT-WATER QUALITY

10.11 INSPECTION OF COMPLETED WORKS

1,076

4,073

10.22 ENERGY CONSERVATION REPORTS

113

11 REAL ESTATE ACTIVITIES - INSPECTIONS, OUTGRANTS, AUDITS

8,473

12.21 OPERATIONAL PLANS

13 OSHA ACTIVITIES

14 PREVENTION OF OBSTRUCTIVE \& INJURIOUS DEPOSITS

896

16 LAW ENFORCEMENT

2,814

Total:

99,907 


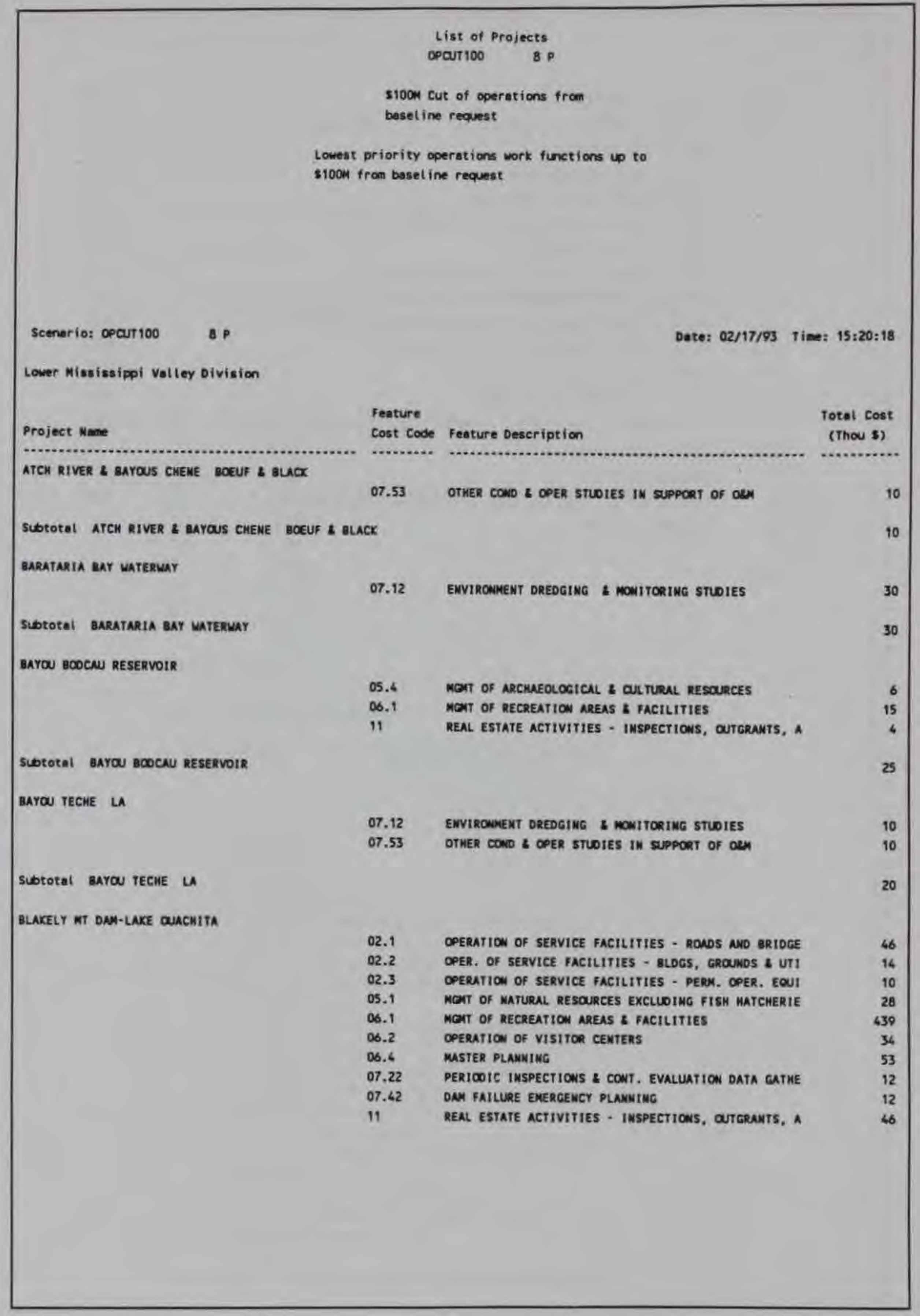




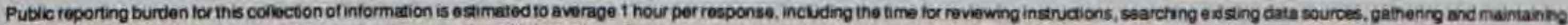

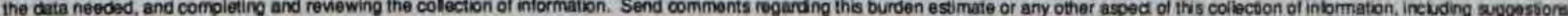

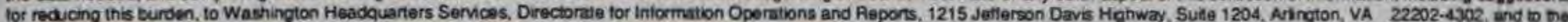
Office of Managemem and Budget. Paperwork Reduction Projact (0704-0188), Washington. DC 20503.

\begin{tabular}{|l|l|l}
\hline 1. AGENCY USE ONLY (Leave blank) & $\begin{array}{l}\text { 2. REPORT DATE } \\
\text { December 1994 }\end{array}$ & $\begin{array}{l}\text { 3. REPORT TYPE AND DATES COVERED } \\
\text { Final report }\end{array}$
\end{tabular}

4. TILE AND SUBTITLE

The Application of a Decision Support System to U.S. Army

Corps of Engineers Civil Works O\&M Budget Analysis

5. FUNDING NUMBERS

Work Unit 32717

6. AUTHOR(S)

Stephen H. Scott

7. PERFORMING ORGANIZATION NAME(S) AND ADDRESS(ES)

U.S. Ammy Engineer Waterways Experiment Station

3909 Halls Ferry Road, Vicksburg, MS 39180-6199

8. PERFORMING ORGANIZATION

REPORT NUMBER

Technical Report HL-94-18

9. SPONSORING/MONITORING AGENCY NAME(S) AND ADDRESS(ES)

U.S. Army Corps of Engineers

10. SPONSORING/MONITORING AGENCY REPORT NUMBER

Washington, DC 20314-1000

11. SUPPLEMENTARY NOTES

Available from National Technical Information Service, 5285 Port Royal Road, Springfield, VA 22161.

128. DISTRIBUTION/AVAILABILTYY STATEMENT

12b. DISTAIBUTION CODE

Approved for public release; distribution is unlimited.

13. ABSTRACT (Maximum 200 words)

This Improvement of Operations and Maintenance Techniques (IOMT) work unit was designed to provide decisionmaking tools to managers involved in the allocation of funding for the U.S. Army Corps of Engineers (USACE) Civil Works Operations and Maintenance projects. These tools, commonly referred to as Decision Support Systems (DSS), provide users with enhanced analytical capabilities for determining the impacts of funding decisions, as well as financial analysis capability for showing the distribution of funds. The DSS concept used in this research was based on a commercially available database (R:BASE) with custom analysis tools added for flexibility. The budgetary data used by the prototype system was obtained through the Automated Budget System (ABS), an existing Corps information system that contains budget data for all the USACE Operations and Maintenance (O\&M) Civil Works projects. This report describes the conception, design, and prototype applications of a DSS developed for providing budget data analysis capabilities at Headquarters, U.S. Army Corps of Engineers (HQUSACE) level and the field level (USACE Division level) of O\&M budget development. The report describes the design and capabilities of the budget DSS and the prototype applications at HQUSACE and the Ohio River Division, USACE.

14. SUBJECT TERMS

Decision support systems

Hydraulic structures

Public works

15. NUMBER OF PAGES

58

16. PRICE CODE

17. SECURITY CLASSIFICATION OF REPORT

UNCLASSIFIED
SECURTY CLASSIFICATION OF THIS PAGE

UNCLASSIFIED
SECURTYY CLASSIFICATION OF ABSTRACT 